\title{
CONTEMPORARY FIBRE LEVEL IN NON-NARCOTIC VARIETIES OF HEMP (CANNABIS SATIVA L.)
}

Laiko I. M., Vyrovets V. H., Kyrychenko H. I., Mishchenko S. V., Kmets I. L.

Research Station of the Bast Crops of the Institute of Agriculture of Northern East of NAAS, Ukraine

Utilization of hemp stalks (Cannabis sativa L.) for energy purposes is a promising field of its application, so long as it is possible to use for fuel both whole stalk and waste products after its processing (awnchaff). Hemp stalk has a high calorific value, which is slightly inferior to coal, but exceed those for soft wood and peat. Despite intensive breeding works aimed at reducing tetrahydrocannabinol content, it became possible to keep the primary value of the crop that is an ability to form a good yield of stalks and fibre. As a result of many years of breeding work obtained were non-narcotic monoecious hemp varieties Hliana, Hlukhivskiy 46, Hlukhivski 51 with fibre content 30.0 to $38.9 \%$. Of these, the most promising for the fibre production is variety Hlukhivski 51 . By fibre yield, this variety exceeds standard one by $1.5 \mathrm{t} / \mathrm{ha}$.

\section{Key words: hemp, fibre, stalk, variety, breeding, tetrahydrocannabinol}

Introduction. The global energy crisis turns researchers' look for searching new kinds of energy carriers. Such energy carriers can be agricultural products that are considered to be renewable energy sources. Hemp is the most renewable energy source. Its main feature is large accumulation of wood: one hectare of hemp gives much more wood than forest species in one year. Thus, the annual growth of pine is $2.5 \mathrm{~m}^{3}$ per hectare, whereas in hemp at the average straw yield of $5 \mathrm{t} /$ ha it makes $5.6 \mathrm{~m}^{3}$ per hectare, and given high yield, twice as much [1].

Analysis of publications, pose the problem. Utilization of hemp stalks for energy purposes is a promising area of the plant application, so long as it is possible to use for fuel both whole stalk and waste products after its processing (awnchaff). Hemp stalk has a high calorific value, which is slightly inferior to coal, but exceed those for soft wood and peat. Hemp stalks after harvesting can be used as an energy fuel in the form of large packages (coils, bales) or after its appropriate processing in the form of briquettes, pellets, granules, etc [2].

One of the modern breeding directions on hemp is creating varieties of high fibre content and stalk yield to increase the profitability of agricultural production.

Hemp fibre, along with the other crops fibre such as flax, kenaf, nettle, jute, abutilon, cotton, etc. consists of separate elementary fibres whose length ranges from 3.5 to $4.0 \mathrm{~cm} \mathrm{[3].}$

Elementary cells and fibrous bundles are divided into primary and secondary. Primary fibre is long; it passes through the entire stem. In hemp, unlike abutilon and kenaf, primary fibre is originally better than the secondary one. In cross-section, fibre bundles are placed in a ribbon, with primary fibre cells occur in two layers and different directions, according to research by I.M. Laiko [4]. Layer of elementary fibres is located closer to endoderm and presented as fibrous bundles of elongated shape in tangential direction. The second layer differs by its bundles of rounded shape and is concentrated in the radial direction. This feature is clearly expressed in low-fibre varieties rather than high-fibre ones.

Fibre quality characteristics are fullness of elementary cells, even cells of the first and the second primary fibre layer as well as the average density of connections in a cluster of cells, which contributes to a better separation of fibre into elementary fibres (Fig. 1). These characteristics should be combined with optimum thickness of the elementary fibre layer and high content of fibre. The intensity of the fibre formation increases till the hemp flowering stage, which almost ends before the period of ripening seeds in monoecious hemp varieties. 


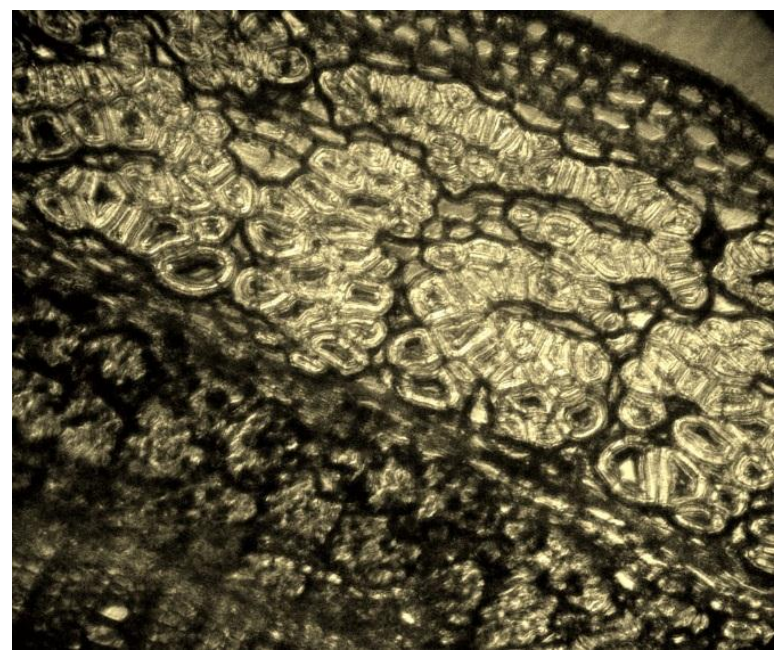

Figure 1. Cross-section of hemp stem

At the beginning of breeding work (1930-40th), fibre content in the stems of hemp fluctuated between $12-20 \%$. For about 40 years, fibre content in dioecious hemp varieties has been increased from 28 to $30 \%$. With the emergence of new monoecious hemp, the question of its practical value arose too. With the aid of intense selection fibre content in plants of monoecious hemp varieties has been raised to the level of $30-32 \%$, same as in high-performance dioecious hemp varieties.

The current level of fibre content in hemp stalks has been provided due to development of many methods of analysis and selection [5, 6], investigation of the anatomical structure of the stem in various dioecious and monoecious varieties [7-11], the disclosure of relation between performance traits of stem and fibre content influencing stem mechanical function [12-17].

Materials and methods. Breeding to improve fibre content was carried out according to family and group selection while using express-test for determining the presence of cannabinoids before flowering, determination of cannabinoids by thin layer chromatography, phenological observations, biometric measurements of plants, analysis of the plant productivity structure, anatomical analysis of stem on the ground of fibre layer thickness, technological assessment of hemp plants on the fibre content and its quality, methods of mathematical statistics. Research was carried out at the Research Station of the Bast Crops of the Institute of Agriculture of Northern East of NAAS located on the border of the Forest-Steppe and Polissia. Several original techniques and methods were used [18-21].

Results and discussion. A feature of the current stage of breeding work is the creation of high-stable monoecious non-narcotic hemp varieties. High performance can be considered only at presence of the above biological characteristics. Despite intensive breeding work for almost 40 years to reduce the amount of tetrahydrocannabinol, it became possible to maintain the primary value of the crop, i.e. the ability to form stalk yield from 7.5 to $8.5 \mathrm{t} / \mathrm{ha}$ and higher, seed yield from 1.0 to $1.3 \mathrm{t} / \mathrm{ha}$, fibre content at the level 28 to $30 \%$. In addition, some hemp varieties such as Hlukhivskyi 46 have fibre content of 34.2\% (2014). Moreover, all varieties feature high content of long fibre (10 to $12 \%$ ).

The most promising variety on the basis of high fibre content is monoecious hemp variety Hlukhivski 51. The efficiency of breeding work on this variety was provided by family and group selection of the best families and plants according to new developed "Method of assessment of individual plants of monoecious hemp varieties on fibre content before flowering." Over the past three years it shows a very high fibre content.

According to the results of the estimation nursery in 2012, it was found $44.2 \%$ families contained 33.6 to $35.5 \%$ fibre, $25.0 \%$ families contained 35.6 to $37.5 \%$ fibre and $7.7 \%$ families contained more than $37.5 \%$ fibre. The average content of fibre was established at the level of $34.6 \%$ (Table 1). In 2013, the distribution of families in Hlukhivski 51 variety on fibre content showed extraordinary results in the estimation nursery. For the first time received was population 
of Hlukhivski 51 with the average content of fibre in families of $39.8 \%$ versus $31.9 \%$ in the standard variety Hliana, that showed an increase of 7.9\%. These results were confirmed in 2014. Families of $44.7 \%$ fibre content were revealed. More than half of the families $(55 \%)$ featured fibre content of 38.1 to $44.7 \%$.

Table 1

Distribution of families of Hlukhivski 51 variety according to fibre content, estimation nursery $15 \times 5 \mathrm{sm}$

\begin{tabular}{|c|c|c|c|c|c|c|c|c|}
\hline \multirow[b]{2}{*}{ Year } & \multirow{2}{*}{$\begin{array}{c}\text { Number } \\
\text { of fami- } \\
\text { lies }\end{array}$} & \multicolumn{6}{|c|}{ Number of families with fibre content, $\%$} & \multirow[b]{2}{*}{ Average, $\%$} \\
\hline & & $<29.5$ & $\begin{array}{c}29.6- \\
31.5\end{array}$ & $\begin{array}{r}31.6- \\
33.5\end{array}$ & $\begin{array}{c}33.6- \\
35.5\end{array}$ & $\begin{array}{c}35.6- \\
37.5\end{array}$ & $>37.5$ & \\
\hline 2012 & 52 & 3.9 & 7.7 & 11.5 & 44.2 & 25.0 & 7.7 & 34.6 \\
\hline 2013 & 13 & - & - & - & 7.7 & 7.7 & 84.6 & 39.8 \\
\hline 2014 & 31 & - & - & 6.5 & 6.5 & 22.6 & 64.5 & 38.1 \\
\hline
\end{tabular}

Note. Average value for Hliana standard variety in 2012 was 30.0\%; in $201331.9 \%$, in 2014 $32.3 \%$.

Effect of selection on fibre content during 2004-2013 in the breeding nursery is shown in Table 2.

Table 2

Distribution of elite plants of Hlukhivski 51 varietiey according to fibre content, breeding nursery

\begin{tabular}{|c|c|c|c|c|c|c|c|c|c|c|}
\hline \multirow{2}{*}{ Year } & \multicolumn{10}{|c|}{ Distribution of families according to fibre content, \% } \\
\cline { 2 - 13 } & $16.2-$ & $18.9-$ & $21.5-$ & $24.1-$ & $26.7-$ & $29.3-$ & $31.9-$ & $34.5-$ & $37.1-$ & $39.7-$ \\
& 18.8 & 21.4 & 24.0 & 26.6 & 29.2 & 31.8 & 34.4 & 37.0 & 39.6 & 44.4 \\
\hline 2004 & 1.1 & 1.1 & 7.8 & 15.6 & 28.9 & 24.4 & 15.6 & 3.3 & 2.2 & 0 \\
\hline 2005 & 0 & 0 & 1.1 & 8.1 & 21.5 & 28.5 & 26.3 & 9.7 & 4.3 & 0.5 \\
\hline 2006 & 0 & 0 & 0 & 3.3 & 28.9 & 42.2 & 16.7 & 6.7 & 2.2 & 0 \\
\hline 2008 & 0 & 0 & 0.9 & 6.5 & 9.3 & 23.4 & 31.9 & 19.6 & 6.5 & 1.9 \\
\hline 2009 & 0 & 0 & 0.7 & 2.2 & 13.3 & 28.9 & 32.7 & 18.5 & 3.7 & 0 \\
\hline 2010 & 0 & 0.9 & 2.9 & 8.6 & 20.9 & 28.6 & 18.1 & 9.5 & 7.6 & 2.9 \\
\hline 2011 & 0 & 0 & 1.1 & 11.0 & 16.3 & 25.0 & 29.3 & 13.0 & 4.3 & 0 \\
\hline 2013 & 0.4 & 0 & 0.4 & 2.2 & 8.4 & 21.8 & 30.1 & 25.8 & 10.9 & 0 \\
\hline 2014 & 0 & 0.3 & 0.3 & 0.3 & 0.3 & 1.8 & 1.5 & 9.5 & 13.2 & 72.8 \\
\hline
\end{tabular}

The result of breeding work over 10 years is reducing the number of plants with fibre content ranged from 16.2 to $29.2 \%$ : from 54.5 in 2004 to $1.2 \%$ in 2014 and an increasing group of plants containing more than $293 \%$ fibre. Previously, only single plants containing over $37 \%$ fibre could be found out, in 2014 there were $86 \%$ such plants. The presence of a new group of plant with fibre content 39.7 to $44.7 \%$ in the amount of $72.8 \%$ confirms the creation of a new unique breeding material.

In breeding strain test (when sown on the unilateral use, at seeding rate of $75 \mathrm{~kg} / \mathrm{ha}$ ) new variety Hlukhivski 51 has been confirmed to be a high-fibre variety. In 2013, 2014 it differed from standard variety Hliana on fibre content: $36.7 \%$, 38.9\%, against 30.8, 30.4\%, respectively.

Amount of long fibre is $35.8 \%$, against $27.5 \%$ in standard variety. In addition, the variety has seed yield at standard level $(1.11 \mathrm{t} / \mathrm{ha})$ and high stem yield. At the stem yield of $13.9 \mathrm{t} / \mathrm{ha}$ (2014) and fibre content of $38.9 \%$, over 5 t/ha of fibre can be obtained which gives additional income of 1,500 USD from 1 hectare (Table 3 ). 
Performance of varieties in breeding strain test (2014)

\begin{tabular}{|c|c|c|c|c|c|}
\hline \multirow{2}{*}{ Variety } & \multirow{2}{*}{$\begin{array}{l}\text { Vegetation } \\
\text { period, days }\end{array}$} & \multirow{2}{*}{$\begin{array}{c}\text { Plant height, } \\
\mathrm{cm}\end{array}$} & \multicolumn{2}{|c|}{ Yield, t/ha } & \multirow{2}{*}{$\begin{array}{c}\text { Biomass yield } \\
\text { (above-ground part) }\end{array}$} \\
\hline & & & seeds & straw & \\
\hline Hliana, standard & 119 & 235.1 & 1.04 & 7.47 & 10.84 \\
\hline Hlukhivski 51 & 128 & 241.9 & 1.11 & 9.90 & 13.90 \\
\hline Hlukhivskyi 46 & 130 & 265.0 & 1.19 & 8.86 & 13.89 \\
\hline \multicolumn{3}{|c|}{$\operatorname{LSD}_{0.05}$} & 0.20 & 0.88 & 1.16 \\
\hline
\end{tabular}

A unique feature is fibre biological peculiarity. The quality of the fibre on the basis of linear density, tensile strength and number of long fibre remains at the level of selected. Such results in the breeding of monoecious hemp were obtained for the first time.

Conclusions. As a result of breeding work obtained were non-narcotic monoecious hemp varieties Hliana, Hlukhivskyi 46, Hlukhivski 51containing fibre from 30.0 to $38.9 \%$. Of these, the most promising for fibre production is variety Hlukhivski 51. Fibre yield in this variety exceeds that of standard variety by $1.5 \mathrm{t} / \mathrm{ha}$, which makes an additional income of more than of 1,500 USD from 1 hectare.

\section{Список використаних джерел}

1. Конопля [Текст] / под ред. Г. И. Сенченко, М. А. Тимонина. - М.: Колос. -1978. - 288 с.

2. Прогрессивная технология возделывания и уборки конопли [Текст] / Сенченко Г. И., Вировец В. Г., Голобородько П. А. и др. - М.: Агропромиздат, 1987. - 70 с.

3. Арно, А. А. Сетчатая структура лубяного слоя в стеблях канатника, кенафа, джута и конопли и ее роль в системе механических тканей стебля [Текст] / А. А. Арно // Научные труды ЦНИИЛВ. - 1962. - Т. 17. - С. 3-20.

4. Лайко, I. М. Анатомічна будова стебел і вміст канабіноідів у конопель [Текст] / I. М. Лайко, В. Г. Вировець // Наукові основи ведення сільського господарства України в сучасних умовах: тез. доп. - Чабани, 1994. - Ч. 1. - С. 29.

5. Сенченко, Г. И. Повышение содержания волокна в стеблях - основной фактор увеличения продуктивности конопли [Текст] / Г. И. Сенченко, В. Г. Вировец // Селекция, семеноводство и технология возделывания технических культур. - М.: Колос, 1980. С. $155-168$.

6. Таракан, Н. И. Методика выделения первичного и вторичного волокна из стеблей конопли [Текст] / Н. И. Таракан // Биология, возделывание и первичная обработка конопли и кенафа : сб. научн. тр. - Глухов, 1974. - Вып. 35. - С. 49-52.

7. Насонов, В. А. Анатомическая характеристика географических рас конопли [Текст] / В. А. Насонов // Вестник социалистического растениеводства. - 1940. - № 4. - С. 120.

8. Астахова, А. В. Анатомическая характеристика стеблей конопли в зависимости от площади питания [Текст] / А. В. Астахова // Лен и конопля. - 1940. - № 2. - С. 26-28.

9. Содержание волокна и анатомическое строение стебля конопли [Текст] / Е. С. Гуржий, Т. П. Голова, В. С. Мережко и др. // Лен и конопля. - 1968. - № 8. - С. 31-33.

10. Кривошеєва, Л. М. Про співвідношення основних анатомічних структур стебла низьковолокнистих і високоволокнистих сортів конопель [Текст] / Л. М. Кривошеєва // Збірник наукових праць Інституту землеробства УААН. - 1999. - Вип. 1-2. - С. 5-8.

11. Кривошеєва, Л. М. Морфологічні особливості формування волокнистого шару в стеблі конопель [Текст] / Л. М. Кривошеєва // Вісник Сумського державного аграрного університету. - 1999. - Вип. 3. - С. 71-73

12. Логинов, М. И. Изучение содержания луба в стебле конопли в селекционных целях [Текст] / М. И. Логинов // Биология, возделывание и первичная обработка конопли и кенафа : сб. научн. тр. - Глухов, 1971 - Вып. 34. - С. 51-59.

13. Сенченко, Г. И. Взаимосвязь морфологических признаков стебля конопли с содержанием первичного и вторичного волокна [Текст] / Г. И. Сенченко // Лен и конопля. -1970. - № 12. - C. 28-29. 
14. Мигаль, М. Д. Технічна довжина стебла конопель - ознака спадкового підвищення продуктивності рослин за волокном [Текст] / М. Д. Мигаль, Ю. В. Голюк / Цитологія і генетика. - 1998. - Т. 32, № 3. - С. 77-80.

15. Мигаль, М. Д. Дослідження розміру стебла і вмісту волокна конопель як складових продуктивності [Текст] / М. Д Мигаль, Ю. В. Голюк // Вісник аграрної науки. - 1999. № 7. - C. 41-44.

16. Онупрієнко, Л. Г. Вплив генотипу сорту та умов вирощування ознак стебла конопель при селекції на волокнистість [Текст] / Л. Г. Онупрієнко // Збірник наукових праць ННЦ «Нститут землеробства УААН». - 2007. - Вип. 3-4. - С. 146-150.

17. Онупрієнко, Л. Г. Морфо-фізіологічні особливості сучасних високоволокнистих сортів однодомних конопель [Текст] / Л. Г. Онупрієнко, В. Г Вировець / Збірник наукових праць Інституту луб'яних культур УААН. - 2007. - Вип. 4. - С. 92-102.

18. Деякі аспекти селекції на підвищення якості волокна конопель (Cannabis sativa L.) [Текст] / В. Г. Вировець, I. М. Лайко, І. І. Щербань та ін. // Селекція і насінництво. - X., 1993. - Вип. 74. - С. 8-11.

19.3більшення вмісту волокна в стеблах посівних конопель (Cannabis sativa L.) як результат цілеспрямованої комплексної дії селекції [Текст] / В. Г. Вировець, I. М. Лайко, Л. Г. Онупрієнко та ін. // Селекція і насінництво. - Х., 2008. - Вип. 96. - C. 195-204.

20. Онупрієнко, Л. Г. Родинно-груповий добір як один із вирішальних факторів збільшення вмісту волокна у сучасних сортів однодомних конопель [Текст] / Л. Г. Онупрієнко, В. Г. Вировець // Іноваційні напрямки в селекції, генетиці, технології вирощування, збирання, переробки і стандартизації технічних культур : міжнар. наук.-техн. конфер. молодих вчених, 2-4 грудня. 2008 р. - Суми, 2009. - С. 3-8.

21. Спосіб оцінки індивідуальних рослин сортів однодомних конопель за вмістом волокна до початку цвітіння: пат. 93740 Україна: А 01 H 1/04 [Текст] / Лайко I. М., Онупрієнко Л. Г.; заявник і патентовласник Інститут луб'яних культур УААН. - № a 2009 04126; заявл. 27.04.09; опубл. 10.11.10, Бюл. № 21.

\section{References}

1. Senchenko GI, Timonin MA editors. Hemp. Moskow: Kolos; 1978. 288 p.

2. Senchenko GI, Virovets VG, Goloborodko PA et al. Progressive technology of cultivation and harvesting of hemp. Moskow: Agropromizdat; 1987. 70 p.

3. Arno, AA. Reticulum structure of bast layer in stems of abutilon, jute and hemp and its function in the stem strengthening tissue system. Nauchnyie trudyi TsNIILV. 1962; 17:3-20.

4. Layko IM, Virovets VG. Anatomical structure of stem and cannabinoids content in hemp. In: Scientific bases of Agriculture of Ukraine in modern conditions. Chabani; 1994; 1:29.

5. Senchenko GI, Virovets VG. Increased fibre content in stems as a main factor of rising productivity in hemp. In: Breeding, seed production and technology of growing of industrial crops. 1980. p. 155-168.

6. Tarakan, NI. Method for separation of primary and second fibre from hemp stem. Biologiya, vozdelyivanie i pervichnaya obrabotka konopli i kenafa. 1974; 35:49-52.

7. Nasonov, VA. Anatomical characteristics of hemp geographic races. Vestnik sotsialisticheskogo rastenievodstva. 1940; 4:120.

8. Astahova, AV. Anatomical structure of hemp stem subject to growing space. Len i konoplya. $1940 ; 2: 26-28$.

9. Gurzhyi ES, Golova TP, Merezhko VS et al. Fibre content and anatomical structure of stem in hemp. Len i konoplya. 1968; 8:31-33.

10. Kryvosheeva, LM. On correlation between main anatomical structures of stem of high-fibre and low-fibre hemp varieties. Zbirnik naukovih prats Institutu zemlerobstva UAAN. 1999; $1-2: 5-8$.

11. Kryvosheeva, LM. Morphological peculiarities of fibrous layer formation in stem of hemp. Visnik Sumskogo derzhavnogo agrarnogo universitetu. 1999; 3:71-73. 
12. Loginov, MI. Studying bast content in hemp stem with breeding purpose. Biologiya, vozdelyivanie i pervichnaya obrabotka konopli i kenafa. 1971; 34:51-59.

13. Senchenko, GI. Correlation of morphological traits in hemp stem with primary and second fibre content. Len i konoplya. 1970; 12:28-29.

14. Mygal, MD. Technical length of hemp stem as hereditary characters of productivity by fibre. Cytology and genetics. 1998; 32/3:77-80.

15. Mygal, MD. Investigation on stem length and fibre content as components of productivity. Visnik agrarnoyi nauki. 1999; 7:41-44.

16. Onuprienko, LG. Effect of genotype and growing conditions of hemp in breeding aimed at fibre content. Zbirnik naukovih prats NNTs «Institut zemlerobstva UAAN». 2007; 3-4:146-150.

17. Onuprienko LG, Virovets VG. Morphological and physiological specifics of modern high fibre monoecious hemp varieties. Zbirnik naukovikh prats Institutu lubyanikh kultur UAAN. 2007; 4:92-102.

18. Virovets VG, Layko IM, Shcherban II, Migun MP. Some aspects of breeding on increasing hemp Cannabis sativa L. fibre quality. Selektsiya i nasinnitstvo. 1993; 74:8-11.

19. Virovets VG, Layko IM, Onuprienko LG et al. Increased fibre content in stems of Cannabis sativa L. resulted from direct integrated action of breeding. Selektsiya i nasinnitstvo. 2008; 96:195-204.

20. Onuprienko LG, Virovets VG. Family-group selection as a crucial factor of increasing fibre content in modern monoecious hemp varieties. In: New directions in genetics, the technology of growing, harvesting, processing and standardization of industrial crops. Proceeding of the International scientific-practical Conference of young scientists. Sumi; 2009. P. 3-8.

21. Layko IM, Onuprienko LG. Assessment of individual plants of monoecious hemp varieties by fibre content before flowering. Pat. 93740 Ukraine, A 01 H 1/04. 2009.

\section{СОВРЕМЕННЫЙ УРОВЕНЬ ВОЛОКНИСТОСТИ НЕНАРКОТИЧЕСКИХ СОРТОВ КОНОПЛИ (CANNABIS SATIVA L.)}

Лайко И. М., Вировец В. Г., Кириченко А. И., Мищенко С. В., Кмец И. Л.

Опытная станция лубяных культур Института сельского хозяйства Северо-востока НААН, Украина

Применение стеблей конопли (Cannabis sativa L.) на энергетические цели является перспективным направлением использования данного растения, поскольку существует возможность задействовать на топливо как все стебель, так и отходы после его переработки (костру). Конопляный стебель имеет высокую теплотворную способность, которая несколько уступает каменному углю, но превышает аналогичные показатели для мягких пород деревьев и торфа.

Цель и задачи исследований. Одним из направлений современной селекционной работы с коноплей является создание сортов конопли с высоким содержанием волокна и урожаем стеблей, что повысит уровень рентабельности аграрного производства.

Материал и методы. Селекция на повышение содержания волокна проводилась методом семейственно-группового отбора при одновременном использовании: экспресс-анализа для определения наличия каннабиноидов до начала цветения, определения содержания каннабиноидов методами тонкослойной хроматографии, фенологических наблюдений, биометрических измерений растений, анализа структуры продуктивности растений, анатомического анализа стеблей по признаку толщины слоя волокна, технологической оценки растений конопли по содержанию и качеству волокна, методов математической статистики. Исследования проводились на базе Опытной станции лубяных культур Института сельского хозяйства Северо-востока НААН на грани Лесостепи и Полесья.

Обсуждение результатов. В результате многолетней селекционной работы получены безнаркотические сорта однодомной конопли Гляна, Глуховский 46, Глуховская 51 с содержанием волокна от 30,0 до 38,9\%. Из них наиболее перспективный для производства волокна является сорт Глуховская 51. Данный сорт превышает сорт-стандарт по урожаю волокна на 1,5 т / га. 
Выводы. Несмотря на интенсивную селекционную работу в направлении снижения содержания тетрагидроканнабинола, удалось сохранить основную ценность культуры способность формировать высокий урожай стеблей и волокна.

Ключевые слова: конопля, волокно, стебель, сорт, селекция, тетрагидроканнабинол

\section{СУЧАСНИЙ РІВЕНЬ ВОЛОКНИСТОСТІ НЕНАРКОТИЧНИХ СОРТІВ КОНОПЕЛЬ (CANNABIS SATIVA L.)}

Лайко І. М., Вировець В. Г., Кириченко Г. І., Міщенко С. В., Кмець І. Л.

Дослідна станція луб'яних культур Інституту сільського господарства Північного Сходу НААН, Україна

Застосування стебел конопель (Cannabis sativa L.) на енергетичні цілі є перспективним напрямом використання даної рослини, оскільки існує можливість задіяти на паливо як усе стебло, так і відходи після їі переробки (кострицю). Конопляне стебло має високу теплотворну здатність, яка дещо поступається кам'яному вугіллю, але перевищує аналогічні показники для м'яких порід дерев та торфу.

Мета і задачі дослідження. Одним із напрямів сучасної селекційної роботи з коноплями $\epsilon$ створення сортів конопель 3 високим вмістом волокна і урожаєм стебел, що підвищить рівень рентабельності аграрного виробництва.

Матеріал і методи. Селекція на підвищення вмісту волокна проводилась методом родинно-групового добору при одночасному використанні: експрес-аналізу для визначення наявності канабіноїдів до початку цвітіння, визначення вмісту канабіноїдів методами тонкошарової хроматографії, фенологічних спостережень, біометричних вимірювань рослин, аналізу структури продуктивності рослин, анатомічного аналізу стебел за ознакою товщини шару волокна, технологічної оцінки рослин конопель за вмістом і якістю волокна, методів математичної статистики. Дослідження проводились на базі Дослідної станції луб'яних культур Інституту сільського господарства Північного Сходу НААН на межі Лісостепу й Полісся.

Обговорення результатів. У результаті багаторічної селекційної роботи отримані безнаркотичні сорти однодомних конопель Гляна, Глухівський 46, Глухівські 51 з вмістом волокна від 30,0 до 38,9\%. 3 них найбільш перспективний для виробництва волокна $є$ сорт Глухівські 51. Даний сорт перевищує сорт-стандарт по урожаю волокна на 1,5 т/га.

Висновки. Незважаючи на інтенсивну селекційну роботу у напрямі зниження вмісту тетрагідроканабінолу, вдалося зберегти основну цінність культури - здатність формувати високий врожай стебел і волокна.

Ключові слова: коноплі, волокно, стебло, сорт, селекція, тетрагідроканабінол

\section{CONTEMPORARY FIBRE LEVEL IN NON-NARCOTIC VARIETIES OF HEMP (CAN- NABIS SATIVA L.)}

Laiko I. M., Vyrovets V. H., Kyrychenko H. I., Mishchenko S. V., Kmets I. L.

Research Station of the Bast Crops of the Institute of Agriculture of Northern East of NAAS, Ukraine

Utilization of hemp stalks (Cannabis sativa L.) for energy purposes is a promising field of its application, so long as it is possible to use for fuel both whole stalk and waste products after its processing (awnchaff). Hemp stalk has a high calorific value, which is slightly inferior to coal, but exceed those for soft wood and peat.

The aim and tasks of the study. One of the directions of modern breeding work with hemp is the creation of cannabis varieties with a high fiber content and crop stalks that will enhance profitability of agricultural production.

Materials and methods. Breeding to improve fibre content was carried out according to family and group selection while using express-test for determining the presence of cannabinoids before flowering, determination of cannabinoids by thin layer chromatography, phenological ob- 
servations, biometric measurements of plants, analysis of the plant productivity structure, anatomical analysis of stem on the ground of fibre layer thickness, technological assessment of hemp plants on the fibre content and its quality, methods of mathematical statistics. Research was carried out at the Research Station of the Bast Crops of the Institute of Agriculture of Northern East of NAAS located on the border of the Forest-Steppe and Polissya.

Results and discussion. Despite intensive breeding works aimed at reducing tetrahydrocannabinol content, it became possible to keep the primary value of the crop that is an ability to form a good yield of stalks and fibre. As a result of many years of breeding work obtained were non-narcotic monoecious hemp varieties Hliana, Hlukhivskiy 46, Hlukhivski 51 with fibre content 30.0 to $38.9 \%$. Of these, the most promising for the fibre production is variety Hlukhivski 51. By fibre yield, this variety exceeds standard one by $1.5 \mathrm{t} / \mathrm{ha}$.

Conclusions. Despite intensive breeding work in the direction of reducing the content of tetrahydrocannabinol, managed to keep the basic value of culture-the ability to generate a high yield of stems and fibres.

Key words: hemp, fibre, stalk, variety, breeding, tetrahydrocannabinol

УДК 581.524.3:631.147:631.4:631.8:631.95

\section{ПРОЯВИ МОДИФІКАЦІЙНОЇ ЗДАТНОСТІ ГЕНОТИПІВ ТРИТИКАЛЕ ОЗИМОГО ЛІСОСТЕПОВОГО ТА ПОЛІСЬКОГО ЕКОТИПІВ}

Москалець В. В., Москалець Т. 3.

Білоцерківський національний аграрний університет, Україна

Експериментально досліджено біоценотичні прояви модифікаційної здатності генотипів тритикале озимого лісостепового та поліського екотипів залежно від агроекологічних чинників. Сорти тритикале озимого вивчено як екобіоморфічні геоценоконсорції, що визначило їх агроекологічну оцінку залежно від генотипових та фенотипових характеристик (зимо-, посухостійкість, площа листкової поверхні, стійкість проти хвороб і шкідників, урожайність та якість зерна та ін.). Запропоновано схему створення стійких високопродуктивних фітоценозів тритикале озимого на різних ієрархічних рівнях (аутекологічному, демекологічному, консорційному, зональному, біоценотичному, екосистемному) шляхом виведення та запровадження екоморф (гібридів, ліній) з низкою цінних господарських та екологічних ознак.

Ключові слова: екоморфи тритикале озимого, різні умови екотопу, технологія вирошування, урожайність, якість зерна, аутекологічний, демекологічний та синекологічний рівні досліджень

Вступ. Екосистемний підхід розкриває комплексність і динамічну природу екосистем (A. G. Tansley, 1935) та є важливим у розробці науково-обгрунтованої практики ведення сільського господарства майбутнього. Тритикале (Triticosecale Wittm. ex A. Camus) як перший синтезований людиною злак є відносно новою культурою, успішна популяризація якої вимагає всебічного її вивчення на різних ієрархічних екологічних рівнях (аутекологічному, демекологічному, консорційному, зональному, біоценотичному, екосистемному).

Аналіз літературних даних, постановка проблеми. Зростаючий інтерес до тритикале в країнах світу й Україні викликаний його високими потенційними можливостями, а саме: високою екологічною валентністю в агрофітоценозах щодо несприятливих умов кліматопів та едафотопів, конкуруючою біоценотичною здатністю в агробіогеоценозі і загалом кризою у продовольчій й екологічній сферах, що є не лише землеробською, але й соціально-

(C) В. В. Москалець, Т. З. Москалець. 2015.

ISSN 0582-5075. Селекція і насінництво. 2015. Випуск 107. 